\title{
Fermentation technology as a driver of human brain expansion
}

Katherine L. Bryant ${ }^{{ }}$, Christi Hansen², Erin E. Hecht ${ }^{\star_{3}}$

Wellcome Centre for Integrative Neuroimaging, Centre for Functional MRI of the Brain (FMRIB),

Nuffield Department of Clinical Neurosciences, University of Oxford, Oxford, United Kingdom

2Hungry Heart Farm and Dietary Consulting, Conley, Georgia, United States

sDepartment of Human Evolutionary Biology, Harvard University, Cambridge, Massachusetts, United States

${ }^{*}$ co-corresponding authors 


\section{Abstract}

Hypothesis/Thesis Statement: the consumption of externally fermented foods acted as the initial metabolic trigger enabling hominid brain expansion

Because brain tissue is metabolically expensive, it is thought that the evolution of humans' large brains was only possible through a concomitant reduction in the size of another expensive organ system, the gut. However, this gut reduction must have itself been made possible by dietary changes, the nature of which are still unclear. Here, we propose that the initial metabolic trigger of hominid brain expansion may have been the consumption of externally fermented foods. We define "external fermentation" as occurring outside the body, as opposed to the internal fermentation that occurs through the gut microbiome. This practice could have begun accidentally and with limited understanding, but over time, fermentation technologies may have become increasingly intentional, socially-transmitted, and culturally-reinforced. We detail the mechanisms by which external fermentation can mediate the evolution of increased brain size, as well as a reduction in gut size, by increasing the bioavailability of macro- and micronutrients while reducing digestive energy expenditure. Importantly, we calculate that the reduction in human gut size relative to modern apes is mainly due to a reduction in the colon, the site of internal fermentation. We also discuss the explanatory power of our hypothesis relative to others, including realistic plausibility in hominids with brains roughly the size of modern chimpanzees. Finally, we survey external fermentation practices across human cultures to demonstrate its viability across a huge range of 
environments, temperatures, and food sources. We close with suggestions for empirical tests.

\section{Introduction: The Problem of Hominin Brain Expansion}

Human brains are notable for their large size. Over the course of 2 million years of evolution, the human brain has tripled in volume. Australopiths possessed brain volumes that were roughly the size of our closest living ape relatives, chimpanzees and bonobos (Pan troglodytes and Pan paniscus) (Holloway 1970; Tobias 1963; Dart and Salmons 1925). With the appearance of Homo, brain expansion in the human lineage began to accelerate, and continued through to the emergence of $H$. sapiens and $H$. neanderthalensis. Although we have much information on the timeline and extent to which the human brain has expanded in our evolution, the mechanisms which drove this expansion are more difficult to determine. Several theories have been proposed, briefly summarized below.

\section{Metabolic constraints on brain evolution}

The Expensive Tissue Hypothesis (Aiello and Wheeler 1995) argues that the expansion of brain size in the hominin lineage required the reallocation of resources from the digestive system. In this view, the limiting factor for brain expansion is the availability of caloric resources, because brain tissue is metabolically expensive compared to most other tissue. Mutations leading to increased brain size, though they might support more 
adaptive behavior by the organism, could not actually be adaptive if they carried with them an increased risk of starvation. A reduction in the amount of gut tissue, which has metabolic needs similar to brain tissue, would free up the calories that would otherwise be used to support and maintain digestion and permit its reallocation to supporting the brain. Supporting this model is the fact that in addition to having relatively large brains, the size of the human gastrointestinal tract is $60 \%$ of that expected for a primate of our size (Aiello and Wheeler, 1995). However, because gut tissue is itself responsible for extracting nutrients from food, mutations leading to reduced gut size could not be adaptive without a prior shift to a more energy-dense, easy-to-digest food source. The Expensive Tissue Hypothesis has generated extensive empirical research, including studies that support this model (Kaufmann et al., 2003; Kotrschal et al., 2011; Tsuboi et al., 2015; Jin et al., 2015; Liao et al., 2016) as well as several that did not find a direct, causal tradeoff between metabolic investment in different tissue types, or instead support a more complex relationship with other metabolic investments (Isler and van Schaik, 2005, 2006; Liu et al., 2014; Kotrschal et al., 2015). In particular, in a study of over 100 mammalian species, a consistent inverse relationship between gut size and brain size was not observed (Navarette et al., 2011). In a revised and elaborated model, Isler and van Schaik (2014) emphasize a complex system of tradeoffs between fitness benefits and multiple energetic costs including development, reproduction, digestion, and locomotion, where the cognitive benefits of a larger brain can only produce an increase in net fitness if the corresponding energetic costs are accounted for; notably, dietary changes are one proposed mechanism that could contribute to this. 
This key point —-that brain size increases are evolutionarily limited by metabolic constraints -- has led to a search for possible changes in diet during the period when encephalization quotients began to depart from earlier anthropoids. Some proposed changes include increased meat consumption via hunting or scavenging, a specialization for the consumption of starchy underground tubers, or the development of cooking technology using fire.

\section{Proposed dietary specializations of early human ancestors}

Increased meat-eating has been argued to have been central to human evolution (Speth 1989; Katharine Milton 1999). Aiello and Wheeler (Aiello and Wheeler 1995) have further proposed that meat-eating is a plausible source of the extra calories needed to allow for brain expansion, and analysis of gut morphology in humans suggests it may be adapted to an intermediate diet with aspects of both frugivory and carnivory (Mann 2000). The archaeological record also supports the importance of meat eating in human ancestors, with fossil evidence of butchery in early Homo (Semaw 2000; de Heinzelin et al. 1999). It is certainly inarguable that modern human diets frequently involve more meat consumption than our anthropoid relatives, and data from modern hunter-gatherers support this view; however, some authors (e.g., (Cordain et al. 2002) argue that evidence for human hunting appears later in human evolution - in the Middle to Late Paleolithic. Another possibility is that meat was acquired by other means. 
(Binford 1985) proposed scavenging after carnivores have finished with a carcass, rather than hunting, was the most likely source of meat for human ancestors. Archaeological evidence has favored scavenging over hunting (Capaldo 1997; Blumenschine 1986) but evidence from modern hunter-gatherers suggests scavenging is less important than previously claimed (O'Connell, Hawkes, and Jones 1988). More recent analyses of the archaeological record indicate that passive scavenging by hominins offered low meat yields (Domínguez-Rodrigo 2002; Domínguez-Rodrigo and Pickering 2003). Bunn and colleagues have proposed that "power scavenging" better explains the patterns of butchery found in the hominin archaeological record (Henry T. Bunn and Ezzo 1993; H. T. Bunn 1996). In this model, human ancestors (Homo) are proposed to have confronted carnivores to drive them from fresh kills in order to obtain more valuable portions of meat than are available to passive scavengers.

Another candidate modification to early hominin diets is the consumption of underground storage organs, or tubers (Hatley and Kappelman 1980). The importance of foraging in human evolution, particularly linked to the Grandmother Hypothesis, has also been highlighted in the tuber-based model of increased calories (O'connell, Hawkes, and Blurton Jones 1999). The importance of tubers as a source of calories for hominins has been debated, however. One frequently cited source of nutritional data (Vincent 1985) calculated the caloric value of the //ekwa tuber using samples of tubers to determine calories per gram and then multiplying by the total mass of the unearthed tuber. But in the field, Hadza hunter-gatherers discard large fibrous portions of foraged wild tubers during consumption (Schoeninger et al. 2001). These authors found that in 
addition to being labor-intensive to unearth, wild foraged tubers have as little as $1 / 4$ of the caloric density reported by Vincent (1985), even after cooking.

Another possibility is that the modifications to food through cooking provided the necessary additional calories and nutrients to support a reduction of gut and increase in encephalization (Wrangham et al. 1999). The hypothesis has been extended to encompass others. For example, cooked tubers have been proposed as an important component of the "cooked foods" diet (O'connell, Hawkes, and Blurton Jones 1999; Wrangham et al. 1999; Hatley and Kappelman 1980) and it has been suggested that scavenged carcasses were cooked to mitigate microbiological contamination (Smith et al. 2015). The trend of reduction of molar size in hominin evolution, suggested to be an adaptation from moving from tougher to softer foods (McHenry and Coffing 2000), fits well with this hypothesis (Zink, Lieberman, and Lucas 2014). The benefits of cooking increase in bioavailability of calories, easier mechanical digestion (especially chewing), and the lowering of energy requirements for digestion - are undoubtable. However, there is a lack of archaeological evidence for the usage of fire by australopiths and early hominins; the earliest date for the evidence of fire by hominins is frequently cited at 0.5 mya by $H$. erectus during the Middle Pleistocene (James et al. 1989). Evidence for fire mastery in the Lower Pleistocene (Goren-Inbar et al. 2004) still puts this behavior well after the initial emergence of $H$. erectus, which is well after selection for brain expansion put hominins on a different course than the Pan lineage. It is almost certainly the case that the actual origins of human-controlled fire predate its oldest surviving archaeological evidence. However, more importantly, mastery of fire technology 
requires individuals to have the cognitive capacity to plan, create, maintain, and use fire effectively; this seems a tall order for an organism with a brain-to-body ratio not much exceeding that of modern nonhuman apes. This suggests that we should continue to search for other mechanisms that could have kicked off our ancestors' initial encephalization.

\section{A New Hypothesis: External Fermentation}

If we are to explain the dietary changes that supported brain expansion and gut reduction in the hominin lineage, we will need to identify strategies that were accessible by individuals with brains that were roughly the size of a chimpanzee's. Here, we outline a novel hypothesis, the External Fermentation Hypothesis (Figure 1). Central to this hypothesis is the realization that the gut is itself a machine for internal fermentation: digestion is accomplished via the the endogenous microbiome. Culturally-transmitted food handling practices which promoted the externalization of this functionality to the extra-somatic environment could have offloaded energetic requirements from the body and freed up the surplus energy budget for brain expansion.

In this paper, we begin with a mechanistic discussion on how external fermentation provides adaptive benefits: it increases macronutrient absorption; it increases the bioavailability of micronutrients, some of which are essential for brain development and function; it supports internal fermentation by the endogenous microbiome; and it provides additional immune benefits. Following this, we present evidence that external 
fermentation specifically addressed the expensive tissue problem: the reduction in human gut size is attributable mainly to reduction in the colon, which is the primary site of internal fermentation; furthermore, humans receive a surprisingly low amount of their calories from short-chain fatty acids (SCFAs), which are the products of colon fermentation on carbohydrates. Next, we consider the plausibility and explanatory power of the External Fermentation Hypothesis compared to other hypotheses.

\section{Fermentation plays an important role in digestion}

Fermentation is the breakdown of organic compounds by enzymes into alcohol, acids, or both. When discussed in the context of human metabolism and nutrition, the enzymatic activity typically originates from bacteria, yeasts or both, and transforms starches, sugars, and proteins into alcohol and/or acids. Rather than relying on the microorganisms living inside an animal's gut to ferment macronutrients, external fermentation is carried out by organisms living wild in the environment or on the surface of the organic material itself. Like internal, or intestinal, fermentation, external fermentation increases the bioavailability of ingested nutrients.

Digestion is the process of mechanically and enzymatically breaking down organic food matter into macronutrients small enough for absorption through the intestinal barrier and into the bloodstream. Any foodstuffs not broken down by enzymes, bile or other digestive chemicals pass through the upper gastrointestinal tract unabsorbed, offering the body no nutritional value. The digestion of fibrous, starchy vegetable matter requires 
a specialized digestive system with modifications that support fermentation. In ruminant animals, this is achieved through additional stomachs - these species are known as foregut fermenters. The hindgut fermenters, which include humans and other primates, as well as non-ruminant mammals - have evolved a large colon, large cecum, or both. A large colon and/or cecum means a large amount of surface area for absorption, but it also means a large amount of internal fermentation.

While both the large and small intestine contain active, symbiotic bacteria, the small intestine contains approximately one million bacteria per $\mathrm{mL}$ while the colon contains up to one trillion bacteria per mL (Gibson and Rastall 2004; Sender, Fuchs, and Milo 2016; Whitman, Coleman, and Wiebe 1998). Combined with a longer transit time than the small intestine (approximately 1-4 hours versus 18-39 hours), this means the action within the colon is focused on bacteria-driven fermentation. Although previously it was thought that in humans, the large intestine did little more than resorb water, there is a new focus on the significance of colon for human health, including immune responsivity (O'Hara and Shanahan 2006), nutrient absorption, and energy regulation (KrajmalnikBrown et al. 2012).

\section{Fermentation promotes macronutrient absorption}

Fermentation within the gut increases the body's capacity to absorb macronutrients beyond the normal function of the upper gastrointestinal tract. Fermented soluble fiber provides an average of $2 \mathrm{cal} / \mathrm{g}$, an additional $50 \%$ to the $4 \mathrm{cal} / \mathrm{g}$ available from digestible 
starch and sugars. This energy is only available via the salvaging of otherwise undigested fiber through internal fermentation by gut microbes (World Health Organization 1997; Popovich et al. 1997); CFIA 2017; WHO/UN 1998). Notably, humans purposefully ferment feed for livestock (sileage) in order to increase its digestibility and caloric value. Like starches and sugars, fibers are polysaccharide structures made up of bound glucose molecules and other small carbohydrates. Originating primarily in the cell walls of plants, fibers such as cellulose and pectin are resistant to hydrolyzation by human digestive enzymes and therefore pass through the small intestine unbroken (Messer et al. 2017; Nelms and Sucher 2015; Vanderhoof 1998). Once in the colon, these fibers are fermented by enzymes from gut flora, and the now-available sugars are fermented into acid/base conjugates. These are then further degraded by secondary microorganisms into short chain fatty acids (SCFAs) (Cummings and Macfarlane 1991; Bik et al. 2017; Battcock et al. 1998). Microbial fermentation of carbohydrates into SCFAs is estimated to contribute $2-10 \%$ of total dietary energy in humans (McNeil 1984; Livesey 1995; McBurney 1994). This is small compared to other mammals, which typically derive from $16 \%$ to over $80 \%$ of maintenance energy from the production of SCFAs in the gut (see Table 1).

These fermentation products have important biological functions. More than $80 \%$ of produced SCFAs take the form of either butyrate, proprionate, or acetate (Bik 2017). Butyrate is the preferred energy source for the cells making up the intestinal wall of the colon, and feeds the rapidly reproducing colonocytes while also producing Vitamin K and a variety of B vitamins for circulation (Vanderhoof 1998; Messer et al. 
2017; Markowiak and Śliżewska 2017). Proprionate is absorbed into the bloodstream and provides a precursor for hepatic synthesis of glucose (Nelms and Sucher 2015). Acetate is also metabolized by the liver to synthesize cholesterol and other long chain fatty acids. Additionally, acetate provides energy to a number of organs and tissues including the heart, kidneys, muscle and fat (den Besten et al. 2013; Bik et al. 2017; Ramakrishna 2013; De Filippo et al. 2010).

Protein availability is also enhanced through fermentation, though to a lesser extent than carbohydrates. Fermentation of legumes hydrolyzes large structures into more easily digestible individual amino acids (Katz 2016). Proprionate, a SCFA and metabolite of carbohydrate fermentation, travels to the liver after absorption and acts as a substrate for protein synthesis (De Filippo et al. 2010). Free peptides, amino acids and ammonia-derived nitrogen are synthesized into microbial protein by yeast and fungi, and the availability of essential amino acids such as tryptophan, lysine, and methionine levels also increases as a result of microbial fermentation (Sandhu, Punia, and Kaur 2017; Mackie 2002; Holzapfel 2002).

Thus, fermentation provides increased macronutrient digestibility for both carbohydrates and proteins. These benefits have led public health scholars to recommend increasing the consumption of fermented foods in countries experiencing food insecurity and high infant mortality (Franz et al. 2014; Holzapfel 2002). 


\section{Fermentation promotes micronutrient absorption}

Fermentation is also critical for the absorption of vitamins and minerals. One way this can occur is via actual synthesis of vitamins by bacteria. In the colon, vitamin K2 is synthesized by multiple genera of bacteria (Katz 2012; Ramezani et al. 2016;

Ramakrishna 2013). B complex vitamins are produced from carbohydrate fermentation by alcohol-producing yeasts and Lactobacillus species - this can occur in the gut as well as in the environment (Katz 2012; Ramakrishna 2013; Priyodip et al. 2017). Notably, externally fermenting foods prior to consuming them can increase the amounts of $B$ vitamins (thiamin, riboflavin, and niacin) by up to 10-fold (Sandhu et al. 2017; Battcock et al. 1998).

Another mechanism by which internal and external fermentation increase bioavailablity of micronutrients is through the breakdown of anti-nutritional factors (ANFs). ANFs are compounds found in staple cereals, grains, seeds, legumes and tubers that bind essential nutrients, preventing their absorption in the body.

One group of ANFs includes phytates and oxalates, which are are powerful chelating agents that form complexes with metal cations, preventing absorption of these minerals (Barakoti and Bains 2007; Humer and Schedle 2016; Nikmaram et al. 2017; El-Abasy et al. 2012; Morrison and Savage 2003). Phytate is a salt formed from plants' phosphorus storage compound, phytic acid. Oxalate is commonly found in leafy vegetation, nuts, and tubers; it forms chelates with essential nutrients iron, magnesium, and most 
importantly, calcium (El-Abasy et al. 2012; Morrison and Savage 2003). Iron, zinc, magnesium, and calcium are thus particularly impacted by ANFs found in raw plant matter (Bassiri and Nahapetian 1977), yet sufficient absorption of these is critical for life (e.g., Lopez et al. 2016; Rerksuppaphol and Rerksuppaphol 2018; DiNicolantonio et al. 2018). Interestingly, humans, unlike rodents, produce little phytase in their small intestine (lqbal, Lewis, and Cooper 1994). The bioavailability of minerals is therefore greatly reduced in humans despite their abundance in raw material. Lactobacillus bacteria-driven fermentation is an alternative to phytase -- by lowering the $\mathrm{pH}$, it provides a favorable environment for both bacterial and endogenous phytase within the plant material to hydrolyze the binding phytate and release the bound minerals (Humer and Schedle 2016; Katz 2016). Oxalate can also be degraded through Lactobacillus fermentations, either externally or internally (Bik et al. 2017; Wadamori, Vanhanen, and Savage 2014). Of note, degradation of phytate by external fermentation has been shown to be more effective than heat treatment or cooking due to the decreased phytase bioactivity at a temperature above $80^{\circ} \mathrm{C}$ (Gupta, Gangoliya, and Singh 2015; Mahgoub and Elhag 1998).

Another group of ANFs includes phenolic compounds like tannins that bind to proteins and enzymes, lowering their bioavailability (Nikmaram et al. 2017). Tannins also lower the overall digestibility of amino acids, minerals, and other macronutrients (Nikmaram et al. 2017). External fermentation by Lactobacillus reduces the concentration of tannins in plant foods rendering proteins, digestive enzymes, and important minerals easier to 
metabolize and absorb (Humer and Schedle 2016; Verni et al. 2017; El-Abasy et al. 2012).

One of the best-documented examples of how external fermentation can render poisonous foods edible is the detoxification of cyanogenic glycoside in bitter cassava (aka yuca or manioc), a common staple for hundreds of millions of people living within the Tropical Belt (Battcock, Azam-Ali, and Food and Agriculture Organization of the United Nations 1998; Franz et al. 2014; Padmaja 1995). If consumed unfermented, the cassava releases dangerous amounts of hydrocyanic acid into the gut when cyanogenic glycosides are hydrolyzed by colonic microorganisms and absorbed as cyanide. Through inhibition of cellular respiration, cyanide poisoning can cause convulsions, hypotension, respiratory failure, and decreased heart rate that times may in death (Katz 2012; Padmaja 1995; CDC 2013). When processed properly, cell walls in the fibers of the cassava tuber are softened by Lactobacillus bacteria during soaking, allowing the endogenous enzymes normally sequestered from the cyanogenic glycosides to hydrolyze the toxin. The production of lactic acid during fermentation also acidifies the environment and provides a favorable mileu for other microorganisms to contribute to the hydrolysis of up to $95 \%$ of the toxin prior to consumption (Battcock, Azam-Ali, and Food and Agriculture Organization of the United Nations 1998; Padmaja 1995).

ANFs are present in the leaves, seeds, and other plant materials that make up a significant portion of many primate species' diets, including hominoids. Foraging strategies of primates that consume plants as part of their diet suggest deliberate 
avoidance of plant species with high endogenous ANF content, as well as preference for younger leaves over mature leaves, as a strategy to reduce ANF burden and increase digestibility (Glander 1982), (Garber 1987)). Primates that have folivory-heavy diets have evolved gut specializations for fermentation - either through the evolution of a complex forestomach, as in colobine monkeys (Langer and Others 1988) or through the expansion of the hindgut (caecum and colon) (Cork 1996). Predictably, hindgut fermenters have caecum/colon volumes that correlate positively with the proportion of leaves that make up their total diet (Chivers and Hladik 1980). We propose that external fermentation may represent a parallel, alternative adaptation.

\section{External fermentation supports gut fermentation}

The third mechanism by which external fermentation supports digestion is by supporting and contributing to the gut microflora, which in turn contributes to ongoing enhanced nutrient absorption. It may effectively act as an external reservoir of bacteria necessary for internal fermentation. In other species, this reservoir function is supplied internally by the caecum (Palestrant et al. 2004; Swidsinski et al. 2005). Caecal size is larger in Old and New World monkeys and prosimians than in anthropoids, smaller in cercopithecoid monkeys, and reduced further in hominoids; of the great apes, humans have the most reduced caecum (Scott 1980). Humans and other apes, however, possess a vermiform appendix, located adjacent to the caecum (Scott 1980), which has been proposed to function as a reservoir for beneficial intestinal flora (Randal Bollinger 
et al. 2007), along with small crypts within the colon (Donaldson, Lee, and Mazmanian 2016).

Diets rich in plant material have been shown to increase beneficial bacteria in the human gut by supplying fermentable substrates to existing microorganisms (De Filippo et al. 2010; Markowiak and Śliżewska 2017). Fermented food provides the additional benefit of introducing probiotic compounds that are not present in unfermented, raw or cooked food. These ingested microflora colonize their new environment, contributing diversity to the host microflora and boosting the guts' ability to ferment more polysaccharides into energy and nutrients (Bik et al. 2017; De Filippo et al. 2010; Markowiak and Śliżewska 2017). Ingested probiotic bacteria can also support the health of endogenous microflora. For example, some species of Lactobacillales and Bifidobacteria bacteria produce bacteriocins, toxins that competitively inhibit pathogens (Ohland and Macnaughton 2010; Priyodip, Prakash, and Balaji 2017). Complete colonization is not necessary; in some cases, just transient contact with certain species of microorganisms to enough to beneficially alter existing colonies of bacteria or produce anti-pathogenic metabolites (Ohland and Macnaughton 2010).

\section{External fermentation may provide additional immune benefits}

By supporting the gut flora responsible for internal fermentation, external fermentation may also help protect the host from infection and disease. Once bound to colonic epithelial cells, probiotic bacteria prevent large amounts of pathogenic bacteria from 
colonizing the intestinal wall, reducing their ability to penetrate into the bloodstream and infect the host (Markowiak and Śliżewska 2017; Ohland and Macnaughton 2010). A rich microbiome producing large amounts of SCFA through the fermentation of indigestible carbohydrates is well-linked to decreased inflammation in the gut and a reduction in GI disorders (Bik et al. 2017; De Filippo et al. 2010; Markowiak and Śliżewska 2017; Priyodip, Prakash, and Balaji 2017; Katz 2016; Katz 2012). Certain orders of bacteria such as Lactobacillales and Bifidobacteriales and genera including Bacteroides and Faecalibacterium are known to contribute large amounts of SCFA across human populations, but studies have shown a richer microbiota containing novel bacterial species in diets containing relatively large amounts microorganisms also results in higher quantities of SCFAs (De Filippo et al. 2010; Priyodip, Prakash, and Balaji 2017). As previously discussed, colonic epithelial cells derive the majority of their energy from SCFAs resulting in a direct relationship between the health of intestinal lining and SCFA levels. Diets low in plant fiber force colonic microorganisms to rely on dietary fats and protein, substrates less than ideal for the microbes, resulting in decreased SCFA production. In the absence of adequate fiber, microbes can also degrade the epithelial mucus layer through digestion of mucins secreted by the host putting the consumer at increased risk of intestinal infection (Bik et al. 2017).

In summary, the ingestion of fermented foods provides four critical components to digestion and absorption. First, it increases the digestibility of foods; second, it increases the bioavailability of micronutrients; third, it supports gut fermentation by contributing to host microfloral diversity; and lastly, it supports immune function and 
resistance to disruption of the gut microbiome. These benefits would have been adaptive advantages for our early ancestors, and could have played a key role in human brain evolution, as we describe below.

\section{External Fermentation as a Driver of Hominin Brain Expansion}

The development of external fermentation technology represents a plausible metabolic mechanism leading to brain expansion beginning at our ancestors' divergence from the australopiths. The importance of considering metabolic costs in brain evolution was famously outlined in the Expensive Tissue Hypothesis, in which the reduction of gut tissue in the human lineage permits the reallocation of metabolic resources towards brain tissue, which is metabolically expensive (Aiello and Wheeler 1995). The obvious paradox here is that gut tissue, while metabolically expensive as well, is the site of caloric uptake for the organism. Thus, reduced gut sizes could only evolve if our ancestors were able to exploit a more nutrient-dense and easily-digestible food source. Following mixed results in empirical tests of the Expensive Tissue Hypothesis, Isler and Van Schaik (2014) expanded and elaborated this framework to include tradeoffs between multiple constraints and drivers in brain size evolution, of which metabolic costs and dietary changes are one component. Importantly, while there is debate and disagreement on the extent to which a gut-brain tradeoff is a causal mechanism in brain enlargement in animals generally or in humans specifically, there is widespread agreement that the evolution of larger brains is closely tied to changes in the budget of energy costs and expenditures. 
Aiello and Wheeler examined the relative proportion of the most metabolically expensive tissues outside of the brain: the heart, liver, kidneys, and gastrointestinal tract. This led them to observe that the gastrointestinal tract - stomach, small, and large intestine - was $60 \%$ smaller than predicted for a primate of our size (Aiello and Wheeler 1995). But if we take a closer look at the gastrointestinal tract, we find that the reduction in size is not equal across organs. The volume of large intestine in non-human great apes is twice that of the small intestine (in gorillas, close to five times the volume); whereas in humans, the ratio is reversed, with the colon having approximately one-third the volume of the small intestine (Katharine Milton 1987; Katharine Milton 1999). Aiello and Wheeler compared the expected organ proportions for a primate of our size (using chiefly great apes for comparison) with the observed proportions and found a large difference - however, this difference was not broken down by subcomponents of the gastrointestinal tract.

Using estimations from Milton (K. Milton 1986; Katharine Milton 1987; K. Milton and Demment 1988) on differences between the proportions of small intestine and colon in humans and apes, we calculated the approximate masses of these subcomponents by taking the midpoint values given by Milton (1999) and applying them to the total gastrointestinal tract values from Aiello and Wheeler (1995). Table 2 shows these calculations; Figure 2 shows the relationship between different organ sizes in a hypothetical $65 \mathrm{~kg}$ human with ape-like organ sizes (expected) and the actual proportions of these organ sizes in modern western humans (actual). While total gut 
reduction is impressive (a reduction of over $41 \%$ ), when we look at subcomponents, it's clear that the reduction is not consistent across the board. Small intestine proportion actually increases, from approximately $.4 \mathrm{~kg}$ to $.62 \mathrm{~kg}$ in modern humans, an increase of $58 \%$. The subcomponent which accounts for the largest share of the reduction is the colon. With a predicted ape-like value of $0.85 \mathrm{~kg}$, a typical human instead has an estimated mass of $.22 \mathrm{~kg}$, a reduction of $74 \%$ - the largest reduction of any of the gut subcomponents and any of the other major organs analyzed (Table 2).

What permitted the drastic reduction in colon size in the human lineage? Milton has implicated meat-eating (Milton 1999). It is reasonable to postulate that a smaller colon would reflect a reduction of dependence on fibrous plant material, given that a major function of the colon is to house bacteria that aid in the breakdown of carbohydrates to SCFAs, as described above. This idea is supported by the fact that humans and members of the order Carnivora share small colon size. However, the gut transit time in Carnivora is much faster than in humans. Milton postulates that this difference is due to our evolutionary history as plant eaters, and that meat-eating is nonetheless the most likely candidate for providing the greater nutrient density needed as gut size reduced.

An equally or perhaps more probable explanation is that colon reduction does indeed follow from reduced need to break down fibrous plant material within the digestive tract, but that this reduced need is due not to an increased dependence on meat, but rather to an increase in bioavailability of nutrients before food is consumed -- i.e., external fermentation (Figure 1). 


\section{Plausibility in early hominin lifestyles}

Is this scenario realistically plausible for our australopith ancestors? In our view, the major hurdle is that it requires a cache of food to be stored in a location conducive to fermentation, and remain there for a duration sufficient for it to occur. Notably, the transport and caching of food is something that separates human ancestors from our closest extant primate relatives. Early hominins appeared to have carried food resources to specific locations, as evidenced by concentrations of animal bones in larger than expected quantities; further, evidence suggests stone tools were carried large distances as well, up to 10 kilometers (Potts 1984; Toth and Schick 2009). Combined with the accumulating evidence that stone tools were likely knapped prior to the emergence of Homo (Lewis and Harmand 2016), it has been argued that australopiths were already knapping tools, butchering animals, and carrying and caching both food and tools (Toth and Schick 2009). By contrast, although chimpanzees do occasionally transport tools, distances are frequently less than 500 meters and rarely reach a kilometer (Luncz et al. 2016). Food transport is limited to the transport of meat across short distances; most other food sources are eaten in the location they are acquired (McGrew and McGrew 1992).

Notably, forethought and mechanistic understanding are not requirements for the initial emergence of external fermentation. Our early ancestors may have simply carried food back to a common location, left it there, and intermittently eaten some and added 
more. Re-use of a consistent storage location could have promoted the stability of a microbial ecosystem conducive to fermentation. As new food items were brought back and added to the cache, they could have become inoculated with the microorganisms already present in the location (or on the hominids themselves). Importantly, fermenting microorganisms can persist in a local environment even through the intermittent absence of a substrate. Thus, over time, the fermentation of stored foods could have become quite stable and self-sustaining, and may have even been unavoidable.

External fermentation may have occurred for a protracted period of time in this manner as an epiphenomenon of pre-existing adaptive habits of food transport and storage. Socially-transmitted practices such as the re-use of the same containers or tools would have further promoted the initiation of fermentation and the stability of ongoing ferments. As time went on, additional facilitation may have come from culturally-reinforced norms, such as superstitions about where food must be stored or how long it must rest before being eaten. As brain size and cognitive capacity increased, understanding of the proximate causes and consequences of fermentation could have progressed in a gradual fashion. Over time, strategic control and manipulation of fermentation practices would have become increasingly complex, leading to the modern day, where cumulative culture has led to a remarkable diversity of fermentation practices (see Table 3).

\section{Explanatory power compared to other hypotheses}


We propose that the offloading of fermentation to the extra-somatic environment can provide explanations for evolutionary changes in the human lineage: the increase in brain size as well as the reduction in gut size, particularly the large intestine. The emergence of meat-eating, tuber-harvesting, and cooking have all also been proposed to account for these changes; why should our just-so story be given any additional credence? Below, we consider several explanatory advantages of the external fermentation hypothesis versus other current hypotheses.

\section{Less brainpower required}

In searching for an initial trigger to the upward spiral of human brain expansion, it is important to recognize that it would have to occur in organisms with brains roughly the size of a chimpanzee. The cognitive capacities of chimps may arguably be inferior to those of australopiths, particularly later, larger-brained australopiths. At a minimum, though, we can reason that behaviors which are well within the chimp repertoire were likely to have been attainable by australopiths, and that behaviors which are beyond the chimp repertoire may have at least been challenging for australopiths.

Chimpanzees display a variety of complex, socially learned, instrumental behaviors

oriented toward food, such as "fishing" for termites or honey using sticks, and fashioning spears to hunt monkeys. Notably, among apes, behavioral adaptations to increase net caloric gain are not limited to chimpanzees; for example, gorillas fold leaves in complex ways which increase the efficiency of consumption (Byrne and Byrne, 1993). Perhaps 
the most well-studied example, though, is chimpanzee nut cracking. Juvenile chimpanzees spend years learning to accomplish this using a hammer stone and anvil stone. During this time, they make errors like banging the hammer stone on the anvil stone while the nut is left resting on the ground nearby (Hirata, Morimura, and Houki 2009). This suggests that chimpanzees have difficulty understanding the underlying causal mechanism - i.e., that the nut's shell is opened because it was struck. Despite nut-cracking occurring in a social context with multiple expert and novice crackers in the same location, using the same tools, at the same time, understanding of the causal relationship between percussion and a cracked shell is not socially learned. Instead, each chimpanzee independently "re-discovers" this causal relationship for itself. The social context merely contributes a scaffold in which independent learning can occur (Tennie et al., 2009).

Chimpanzee stone tool use has continued substantially unchanged for at least 4,300 years, as indicated by the discovery of fossil stone tools (Mercader et al., 2007). Thus, animals with brains similarly sized to australopiths are capable of socially transmitting instrumental behaviors which are stable over long periods of time in the absence of underlying causal understanding about how the specific details of the action are related to its end goal. Aspects of behavior that are easily socially transferred by chimpanzees include memory for the objects, tools, and locations that are involved in achieving a particular goal. We propose that this is all that is required for social transmission of fermentation to take hold. 
In comparison with fermentation, the means-ends dependencies between objects, actions, and outcomes in cooking are considerably more constrained and complex. Cooking requires comprehension of causal mechanisms between multiple interacting objects - i.e., a chain of sequential, dependent interactions between fuel, flames, and raw food. This is precisely the type of means-ends dependency that is challenging for chimpanzees. Thus, we propose that external fermentation poses less of a cognitive hurdle than control of fire, and was thus more likely than cooking to impact the gut-brain tradeoff at an earlier point in evolution.

Notably, one experiment did address whether chimpanzees might have some of the cognitive skills necessary for cooking. Warenken and Rosati (2015) presented chimps with a device which, via unseen experimenter manipulation, "transformed" raw food to cooked food, and showed that chimps deliberately used the device to obtain the latter. Beran et al (2016) argue that this experiment reveals more about chimps' food preferences and capacity for bartering or exchange behavior than it does about their capacity for cooking. We propose an alternative but not necessarily mutually exclusive view, namely, that these results provide evidence that chimp-sized brains are capable of understanding and performing the steps required to ferment food: put food in a particular place, wait for it to become transformed, and then enjoy an improved version.

Why is it, then, that nonhuman apes don't engage in external fermentation? A potential explanation may be that despite having the basic cognitive mechanisms, chimps lack 
other, prerequisite, psychological mechanisms required for food caching to occur. One of these may be the ability to delay gratification. Other possibilities include increased social tolerance, food-sharing, and the existence of cultural norms about ownership. These mechanisms are uniquely developed in humans, which are the only ape species known to store food, and may be necessary for the continued existence of a cache of communally accessible food.

\section{No lightbulb moment required}

While the utility of fire and fermentation for food processing could both be discovered accidentally, we argue that this discovery was more probable for fermentation. Naturally-occurring fire is not a daily incident. Opportunities for our ancestors to spontaneously observe fire or notice its potential for cooking must have been sporadic. It is conceivable that accidental cooking may have occurred (for example, the action of wildfire on animal carcasses or buried tubers), but this seems likely to have been infrequent. More importantly, the transition from opportunistic, infrequent access to accidentally-cooked food to a long-term and stable source of extra calories would require a "lightbulb moment:" recognition of the effects of the accidental process, and intentional, deliberate actions to reproduce their causes. In contrast, naturally-occurring fermentation is a daily incident. Bacteria and fungi are everywhere, all the time, and spontaneously colonize food that isn't consumed or otherwise preserved. Moreover, no "lightbulb moment" is required to transform unintentional external fermentation into a stable, ongoing source of extra calories. 


\section{Environmental stability}

Fires require ongoing active effort to maintain, whereas fermentation is largely a passive process. Once started, an ongoing fermentation does not extinguish, and does not require tending or restarting, as fire does. Moreover, this environmental persistence offers more chances for social learning, further supporting the longevity of the practice across generations.

\section{Stable food preservation - a caloric buffer}

Because brain tissue is so energetically expensive, and is intolerant of reduced energy availability, organisms with larger brains are more susceptible to fluctuating availability of food (van Schaik). The evolution of increased adipose tissue in humans is a proposed adaptation to ameliorate this risk; fat provides an "internal buffer" for survival through lean times (Leonard et al., 2003; Navarette et al., 2011). External fermentation practices may have provided a secondary, "external buffer." Fermentation can preserve food for years. Food spoilage is caused by microorganisms, and some of the best inhibitors of microorganisms are other microorganisms. Fermentation allows for the proliferation of non-harmful or beneficial strains which out-compete harmful strains; for example, by-products of fermentation include alcohol and acid, which inhibit further microbial growth, effectively preserving the food. There are other food storage techniques whose effective timescales are within that of fermentation, such as smoking, 
drying, freezing, and salting (notably, often used in combination with fermentation). However, compared to these other methods, we propose that fermentation may have been accomplishable more easily, across a wider range of environments, and by earlier, smaller-brained, less cognitively-complex ancestors.

\section{Summary of explanatory power of the External Fermentation Hypothesis}

Unlike other proposed dietary modifications, a transition to eating fermented foods does not require great leaps in cognitive ability. It does not require advanced planning, as hunting, particularly hunting in groups, would. It does not require the acquisition of a difficult technology, as in fire for cooking. And it can more directly explain, than tubers, meat, or cooking, how colon fermentation could be replaced through dietary changes.

Fermentation accounts for all the benefits that cooked food offers: softer food, higher caloric content, greater bioavailability of nutrients, and protection from pathogenic microorganisms. Fermentation solves several problems. It does not require special materials beyond a place to store food (a hollow, a cave, or a hole in the ground work). It does not require overcoming fear - there is a low barrier to entry. It can be stumbled upon rather than requiring planning and tool use. And it does not require, initially, longterm planning, focused attention, or sophisticated social coordination.

In all likelihood, for most of human history, it was nearly impossible to store food for any length of time without bacterial or fungal growth. Life-threatening illness is a risk of 
some food-borne microbes (e.g., E. coli, salmonella). Thus, it would have been necessary to either keep all microbial growth below potentially toxic levels (via e.g., drying, salting, smoking, or freezing), or encourage high levels of "good" microbial activity to out-compete the bad. The latter seems clearly easier.

\section{Contemporary Human Fermentation Practices}

We can look to current fermentation practices for insight into its role in our past. We have created a detailed list of examples that provide a sense of the widespread scope and impact of fermentation technology on the human diet worldwide (Table 3). Humans deliberately ferment foods of nearly every kind, including fruits, vegetables, grains, legumes, animals (muscle meat, organs, fat and bones), dairy, fish, and shellfish. Fermentation is practiced successfully in a diversity of climatic contexts, from tropical humid conditions to arctic environments. It is accomplished with a wide variety of microorganisms, including bacteria, filamentous fungi, and yeasts. Moreover, fermentation works on a range of timescales from hours to years; it can effectively act as a short-term flavor enhancer or a long-term storage technique.

We present this aggregation of examples as evidence supporting three points. First, given the incredible range of food types and environments that can lead to successful fermentation, it is plausible that this was also possible for the food types and environments of early human ancestors. Second, it seems that fermentation is ubiquitous across extant cultures and can be considered a human universal. This is 
consistent with fermentation having a very early emergence. Third, while cultural practices for fermenting food vary across the globe, it seems clear that humans in general have a taste for fermented food. This preference may be an evolved mechanism which emerged because an attraction to these flavors was adaptive in our shared past. Notably, many fermented foods listed in Table $\mathbf{3}$ such as fish sauce, soy sauce, and vinegar, are condiments - i.e., substances added to other food items mainly for the purpose of improving palatability.

\section{Testing the External Fermentation Hypothesis}

\section{Are preferences for fermented foods innate?}

If our hypothesis is correct, then we might expect to find evolved innate preferences for beneficial fermentation products, or evolved innate aversions to dangerous byproducts of "off" fermentation. Interestingly, it appears that many of the most disparately-regarded foods - seen by some as prized delicacies, and by others as supremely unappetizing are fermented: for example, thousand-year eggs, natto, and Limburger cheese. These preferences appear to be highly culturally-specific, which might be adaptive given the high cultural diversity of fermentation practices and the risks of consuming a ferment gone awry. The same flavors or odors which might signal "good" food in one culture could emanate from "off" ferments in another. Future research could address the extent to which preferences for fermented products are innate, cultural, or may be the product of gene-culture coevolution (Henrich and McElreath 2003). Are they more susceptible to 
cultural learning than other food preferences? Are they more sensitive to experience in a developmental critical period, and/or less flexible after this period closes? Are they heritable, either genetically or epigenetically (Dias et al. 2015)?

\section{Do the risks of external fermentation outweigh the benefits?}

A potential argument against our hypothesis concerns the potential for fermented foods to be colonized by pathogenic microbes. This must certainly have been a risk, but the more relevant question is, how did the risks and benefits of external fermentation compare to the risks and benefits of other potential solutions to the of balancing the metabolic budgetary increase associated with brain enlargement? Hunting, scavenging from large carnivores, and use of fire certainly carry their own risks; perhaps the risks of fermentation were more predictable and thus more reliably mitigable through individual and cultural learning. In the environments and time periods relevant for our hypothesis, what kind of situations might have caused a fermentation to go "off"? How easy would it have been for a hominid with a chimpanzee-sized brain to avoid these risks, either deliberately or via socially-learned canalization of practices? How often would "off" fermentation have catastrophic results versus temporary illness, and how would this have compared to injuries sustained during hunting, scavenging, or fire use? Potential answers to these questions might come from food microbiology investigations where fermentation products are studied under varying environmental conditions, or from field research with existing hunter-gatherer populations. 
Is the human microbiome adapted for consuming fermented food?

Another opportunity to find evidence for or against the External Fermentation Hypothesis may come from examinations of the human microbiome. Interestingly, a comparative analysis with chimpanzees, bonobos, and gorillas indicates that the human microbiome has undergone accelerated deviation from the ancestral ape state, and now shows reduced diversity (Moeller et al., 2014), which may be consistent with increased reliance on external microbial communities. If early humans really offloaded internal fermentation to the external environment, we should expect to see changes in the internal microbial community, and potentially evolutionary cross-talk between internal and external fermenters of human food. Would internal species associated with a particular food become less abundant over time, while the external species proliferated? Would humans' internal flora adapt to now specialize in the post-fermentation product, perhaps with evolved adaptations for tolerating higher levels of fermentation byproducts like acid or ethanol? Can we trace the co-evolution of gut flora and external fermentation flora as human populations have moved around the globe? Could phylogenetic analyses of human gut microbes provide a window onto the onset of fermentation practices in human evolution?

\section{Conclusions}

We have proposed that the acquisition of fermentation technology by early hominins the external fermentation hypothesis - is a good candidate mechanism for human brain 
expansion and gut reduction. The offloading of gut fermentation into an external cultural practice may have been an important hominin innovation that laid out the metabolic conditions necessary for selection for brain expansion to take hold. While the potential importance of fermentation in the evolving human diet has recently been postulated (Dunn et al., 2020), and the reduction in human colon size has long been known (Milton, 1999), to our knowledge, the possibility that external fermentation served as the initial trigger in the human lineage for the expansion of brains and the reduction of the gut specifically, the colon - has so far been unnoticed. We have discussed the adaptive benefits of this hypothesized scenario, its realistic plausibility, and its explanatory power relative to other hypotheses. We invite commentary and experimental tests from the broader academic community. 
Tables and Figures

Table 1

\begin{tabular}{|c|c|c|c|c|}
\hline Species & Latin name & Diet & $\begin{array}{l}\text { Total } \% \text { of } \\
\text { energy }\end{array}$ & Citation \\
\hline Cattle & Bos taurus & $\begin{array}{l}\text { Ruminant } \\
\text { herbivory }\end{array}$ & $72 \%$ & (Siciliano-Jones and Murphy 1989) \\
\hline Sheep & Ovis aries & $\begin{array}{l}\text { Ruminant } \\
\text { herbivory }\end{array}$ & $84 \%$ & $\begin{array}{l}\text { (Bergman et al. 1965; Gray et al. 1967; } \\
\text { Faichney 1969) }\end{array}$ \\
\hline Pony & $\begin{array}{l}\text { Equus ferus } \\
\text { caballus }\end{array}$ & $\begin{array}{l}\text { Monogastric } \\
\text { herbivory }\end{array}$ & $30 \%$ & (Glinsky et al. 1976) \\
\hline Rabbit & $\begin{array}{l}\text { Oryctolagus } \\
\text { cuniculus }\end{array}$ & $\begin{array}{l}\text { Monogastric } \\
\text { herbivory }\end{array}$ & $32 \%$ & $\begin{array}{l}\text { (Hoover and Heitmann 1972; Marty and } \\
\text { Vernay 1984; Parker 1976) }\end{array}$ \\
\hline Beaver & Castor canadensis & $\begin{array}{l}\text { Monogastric } \\
\text { herbivory }\end{array}$ & $19 \%$ & (Hoover and Clarke 1972) \\
\hline Porcupine & Hystrix dorsata & $\begin{array}{l}\text { Monogastric } \\
\text { herbivory }\end{array}$ & $16 \%$ & (Johnson and McBee 1967) \\
\hline Pig & Sus scrofa & Omnivory & $36 \%$ & $\begin{array}{l}\text { (Imoto and Namioka 1978; K. I. Kim, } \\
\text { Benevenga, and Grummer 1978; Rérat et al. } \\
\text { 1987) }\end{array}$ \\
\hline Rat & Rattus norvegicus & Omnivory & $5 \%$ & (M. G. Yang, Manoharan, and Mickelsen 1970) \\
\hline $\begin{array}{l}\text { Mantled } \\
\text { howler } \\
\text { monkey }\end{array}$ & Alouatta palliata & $\begin{array}{l}\text { Monogastric } \\
\text { herbivory }\end{array}$ & $30 \%$ & (K. Milton and McBee 1983) \\
\hline Gorilla & $\begin{array}{l}\text { Gorilla gorilla } \\
\text { gorilla }\end{array}$ & $\begin{array}{l}\text { Monogastric } \\
\text { herbivory }\end{array}$ & $57 \% *$ & (Popovich et al. 1997) \\
\hline Human & $\begin{array}{l}\text { Homo sapiens } \\
\text { sapiens }\end{array}$ & Omnivory & $2-10 \%$ & (McNeil 1984; Livesey 1995; McBurney 1994) \\
\hline
\end{tabular}

Legend: Percentage of maintenance energy derived from the production of short-chained fatty acids

(SCFAs) via gut fermentation. Information adapted chiefly from (Bergman 1990). Values for gorillas were estimated from diet composition and human colonic fermentation rates. 
Table 2

\begin{tabular}{|l|l|l|l|l|l|l|l|}
\hline & Heart & Kidney & Liver & Other Gut & Small Intestine & Colon & Brain \\
\hline Expected & 0.32 & 0.238 & 1.563 & 0.63 & 0.404 & 0.846 & 0.45 \\
\hline Actual & 0.3 & 0.3 & 1.4 & 0.26 & 0.616 & 0.22 & 1.3 \\
\hline$\%$ change & $-6.3 \%$ & $26 \%$ & $-10.4 \%$ & $-58.1 \%$ & $52.3 \%$ & $-74.0 \%$ & $188.9 \%$ \\
\hline
\end{tabular}

Legend: Expected masses in $\mathrm{kg}$ and percentage difference for major organs in a hypothetical $65 \mathrm{~kg}$ human based on great ape values (expected) and observed (actual) measurements in western humans. Data based on Aiello and Wheeler's (1995) compilation of data from Stahl (Stahl 1965), Stephan et al. (Stephan, Frahm, and Baron 1981), and Chivers and Hadlick (Chivers and Hladik 1980). Gastrointestinal tract weights were subdivided based on ratios from Milton (K. Milton 1986; Katharine Milton 1987; K. Milton and Demment 1988). 


\section{Table 3. The Ubiquity of Fermentation Technology}






\section{Figure 1}

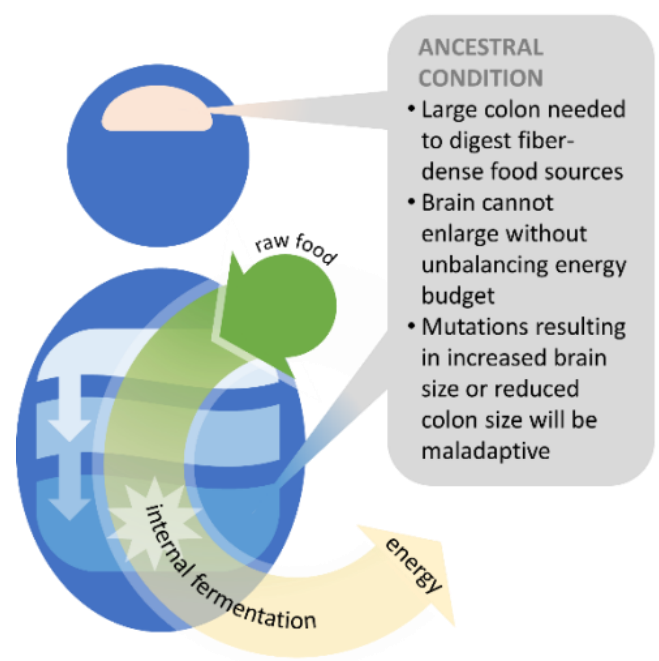

SHIFT IN DIET

- Ingesting externally

fermented food allows

increased macro- and

micronutrient absorption

- Externally cached energy

buffer

SHIFT IN BRAIN

- Net energy surplus

- Mutations resulting in

increased brain size can be

adaptive

SHIFT IN GUT

- Reduced reliance on

internal fermentation

- Mutations resulting in

decreased colon size can

be adaptive

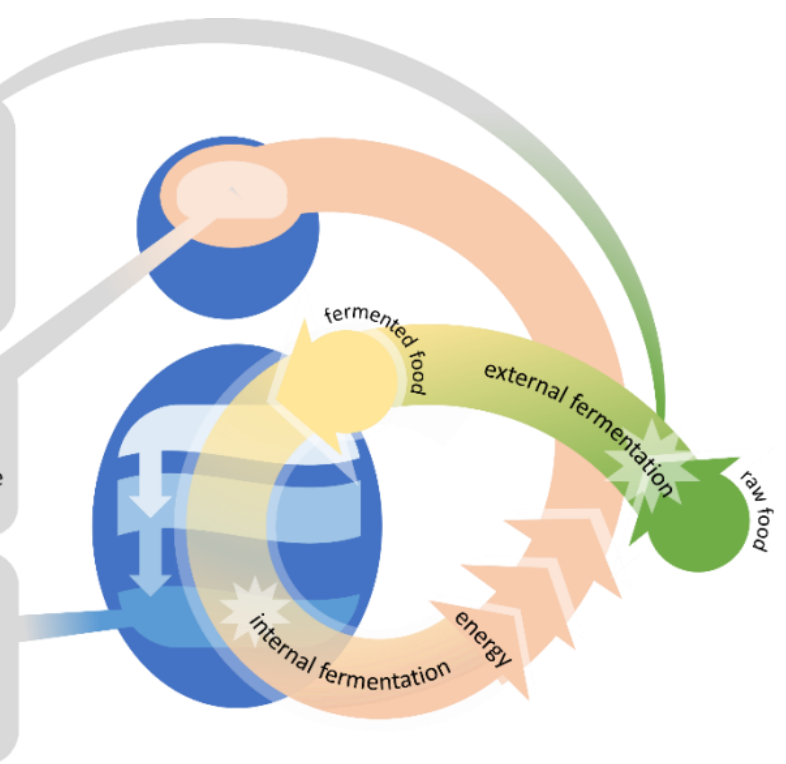

Figure 1 Legend: The External Fermentation Hypothesis 


\section{Figure 2}

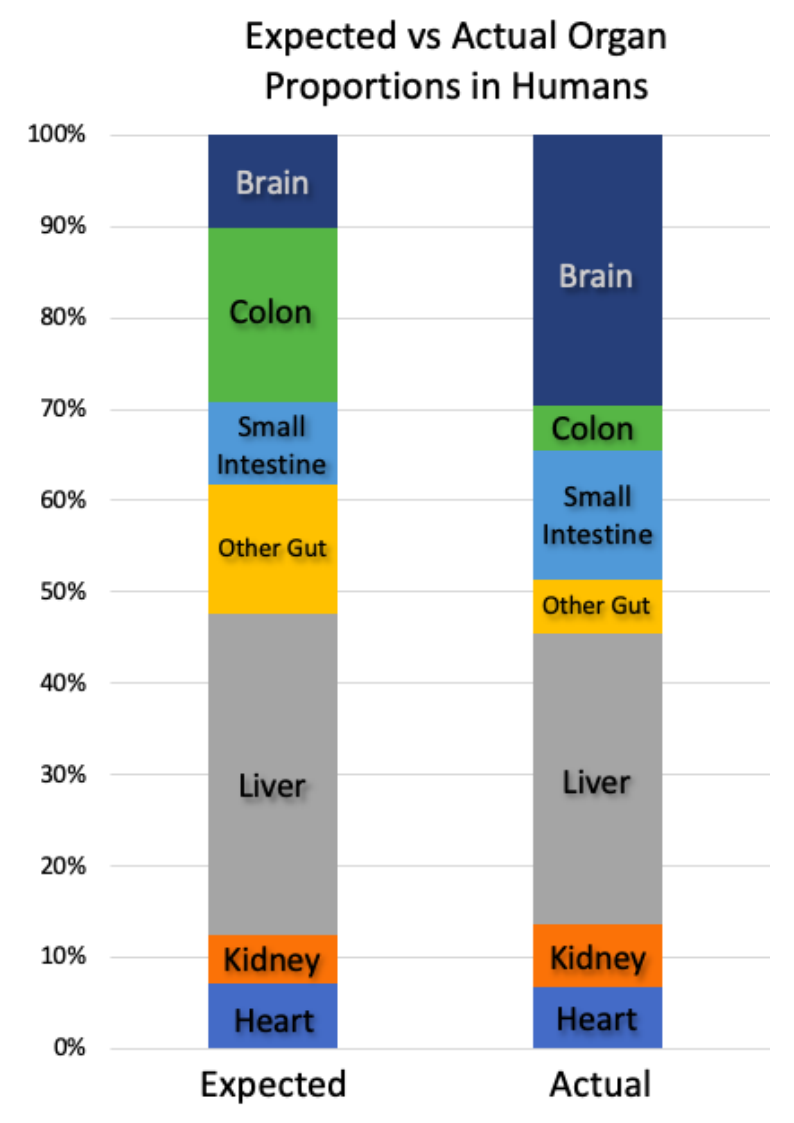

Figure 2 Legend: Proportions of major organs in a hypothetical $65 \mathrm{~kg}$ modern Western human using data from Table 1. "Expected" represents the ratio of organ masses expected if humans had proportions in line with other great apes. "Actual" represents an estimation of the ratios in a typical modern Western human. 


\section{Funding}

K. L. B. is funded by the Biotechnology and Biosciences Research Council (BBSRC; grant BB/N019814/1). E. E. H. is funded by National Science Foundation (NSF grant \#1631563).

\section{Acknowledgements}

The authors would like to thank Matthew C. Maddox for his theoretical contributions early in the development of this hypothesis through his expertise in fermentation technologies. The authors thank Christina Rogers Flattery, Brittany Howell, and Dan Lieberman for their valuable feedback on earlier versions of this manuscript. 


\section{References}

Aiello, L.C., and P. Wheeler. 1995. The Expensive-Tissue Hypothesis: The Brain and the Digestive System in Human and Primate Evolution. Current Anthropology 36, no. 2: 199_ 221.

Akingbala, J.O., O.B. Oyewole, P.I. Uzo-Peters, R.O. Karim, and G.S.H. Baccus-Taylor. 2005. Evaluating Stored Cassava Quality in Gari Production. International Journal of Food, Agriculture and Environment 3, no. 1: 75-80.

Avallone S, Guyot B, Brillouet JM, Olguin E, Guiraud JP. 2001. Microbiological and biochemical study of coffee fermentation. Curr. Microbiol. 42(4):252-56

Bamforth CW. 2008. Food, Fermentation and Micro-Organisms. John Wiley \& Sons

Barakoti, L., and K. Bains. 2007. Effect of Household Processing on the in Vitro Bioavailability of Iron in Mungbean (Vigna Radiata). Food and Nutrition Bulletin 28, no. 1 (March): 18-22.

Başoğlu F, Şahin İ, Korukluoğlu M, Uylaser V, Akpinar A. 1996. A research on the effects of fermentation type and additives on quality and preservation and development of adequate technique in brined vine-leaves production. Turk. J. Agric. For. 20(6):535-45

Bassiri, A., and A. Nahapetian. 1977. Differences in Concentrations and Interrelationships of Phytate, Phosphorus, Magnesium, Calcium, Zinc, and Iron in Wheat Varieties Grown under Dryland and Irrigated Conditions. Journal of Agricultural and Food Chemistry 25, no. 5: $1118-1122$.

Battcock, M., S. Azam-Ali, and Food and Agriculture Organization of the United Nations. 1998. Fermented Fruits and Vegetables: A Global Perspective. Food \& Agriculture Org. ben Omar N, Ampe F. 2000. Microbial community dynamics during production of the Mexican fermented maize dough pozol. Appl. Environ. Microbiol. 66(9):3664-73 
Beresford, T.P., N.A. Fitzsimons, N.L. Brennan, and T.M. Cogan. 2001. Recent Advances in Cheese Microbiology. International Dairy Journal / Published in Association with the International Dairy Federation 11, no. 4 (July 11): 259-274.

Bergman, E.N. 1990. Energy Contributions of Volatile Fatty Acids from the Gastrointestinal Tract in Various Species. Physiological Reviews 70, no. 2 (April): 567-590.

Bergman, E.N., R.S. Reid, M.G. Murray, J.M. Brockway, and F.G. Whitelaw. 1965. Interconversions and Production of Volatile Fatty Acids in the Sheep Rumen. Biochemical Journal 97, no. 1 (October): 53-58.

den Besten, G., K. van Eunen, A.K. Groen, K. Venema, D.-J. Reijngoud, and B.M. Bakker. 2013. The Role of Short-Chain Fatty Acids in the Interplay between Diet, Gut Microbiota, and Host Energy Metabolism. Journal of Lipid Research 54, no. 9 (September): 23252340.

Bik, E.M., J.A. Ugalde, J. Cousins, A.D. Goddard, J. Richman, and Z.S. Apte. 2017. Microbial Biotransformations in the Human Distal Gut. British Journal of Pharmacology (November 8). http://dx.doi.org/10.1111/bph.14085.

Bilger LN, Young HY, Others. 1935. A Chemical Investigation of the Fermentations Occurring in the Process of Poi Manufacture. US Government Printing Office

Binford, L.R. 1985. Human Ancestors: Changing Views of Their Behavior. Journal of Anthropological Archaeology 4, no. 4 (December 1): 292-327.

Blumenschine, R.J. 1986. Carcass Consumption Sequences and the Archaeological Distinction of Scavenging and Hunting. Journal of Human Evolution 15, no. 8 (December 1): 639-659. Bunn, H.T. 1996. Comment on Rose and Marshall. Current Anthropology 37: 321-323.

Bunn, H.T., and J.A. Ezzo. 1993. Hunting and Scavenging by Plio-Pleistocene Hominids: Nutritional Constraints, Archaeological Patterns, and Behavioural Implications. Journal of Archaeological Science 20, no. 4 (July 1): 365-398. 
Byrne RW, Byrne JME. 1993. Complex leaf-gathering skills of mountain gorillas (Gorilla g. beringei): Variability and standardization. Am J Primat 31(4): 241-261.

Campbell-Platt G. 1994. Fermented foods-a world perspective. Food Res. Int. 27(3):253-57

Capaldo, S.D. 1997. Experimental Determinations of Carcass Processing by Plio-Pleistocene Hominids and Carnivores at FLK 22 (Zinjanthropus). Olduvai Gorge, Tanzania. Journal of Human Evolution 33, no. 5 (November): 555-597.

CDC. 2013. Emergency Preparedness and Response: Cyanide. CDC Cyanide. https://emergency.cdc.gov/agent/cyanide/index.asp.

Chaves-López C, Serio A, Martuscelli M, Paparella A, Osorio-Cadavid E, Suzzi G. 2011. Microbiological characteristics of kumis, a traditional fermented Colombian milk, with particular emphasis on enterococci population. Food Microbiol. 28(5):1041-47

Chivers, D.J., and C.M. Hladik. 1980. Morphology of the Gastrointestinal Tract in Primates: Comparisons with Other Mammals in Relation to Diet. Journal of Morphology 166, no. 3 (December): 337-386.

Chou C-C, Ling M-Y. 1998. Biochemical changes in soy sauce prepared with extruded and traditional raw materials. Food Res. Int. 31(6):487-92

Collard, P., and S. Levi. 1959. A Two-Stage Fermentation of Cassava. Nature 183, no. 4661: $620-621$.

Cordain, L., S.B. Eaton, J.B. Miller, N. Mann, and K. Hill. 2002. The Paradoxical Nature of Hunter-Gatherer Diets: Meat-Based, yet Non-Atherogenic. European Journal of Clinical Nutrition 56 Suppl 1 (March): S42-52.

Cork, S.J. 1996. Optimal Digestive Strategies for Arboreal Herbivorous Mammals in Contrasting Forest Types: Why Koalas and Colobines Are Different. Australian Journal of Ecology. https://sci-hub.tw/https://onlinelibrary.wiley.com/doi/abs/10.1111/j.14429993.1996.tb00581.x. 
Cummings, J.H., and G.T. Macfarlane. 1991. The Control and Consequences of Bacterial Fermentation in the Human Colon. The Journal of Applied Bacteriology 70, no. 6 (June): 443-459.

Cutler HC, Cardenas M. 1947. CHICHA, A NATIVE SOUTH AMERICAN BEER. Bot. Mus. Lealf. Harv. Univ. 13(3):33-60

Dakwa S, Sakyi-Dawson E, Diako C, Annan NT, Amoa-Awua WK. 2005. Effect of boiling and roasting on the fermentation of soybeans into dawadawa (soy-dawadawa). Int. J. Food Microbiol. 104(1):69-82

Danilović B, Savić D. 2017. Microbial ecology of fermented sausages and dry-cured meats. Fermented Meat Products: Health Aspects. 127-66

Dart, R.A., and A. Salmons. 1925. Australopithecus Africanus: The Man-Ape of South Africa. $A$ Century of Nature: Twenty-One Discoveries That Changed Science and the World, Edited by Laura Garwin and Tim Lincoln: 10-20.

Davies, F.L., and B.A. Law. 1984. Advances in the Microbiology and Biochemistry of Cheese and Fermented Milk. http://agris.fao.org/agrissearch/search.do?recordID=US201300380433.

De Filippo, C., D. Cavalieri, M. Di Paola, M. Ramazzotti, J.B. Poullet, S. Massart, S. Collini, G. Pieraccini, and P. Lionetti. 2010. Impact of Diet in Shaping Gut Microbiota Revealed by a Comparative Study in Children from Europe and Rural Africa. Proceedings of the National Academy of Sciences of the United States of America 107, no. 33 (August 17): 1469114696.

Deshpande, S.S. 2000. Fermented Grain Legumes, Seeds and Nuts: A Global Perspective. Food \& Agriculture Org.

DiNicolantonio, J.J., J.H. O'Keefe, and W. Wilson. 2018. Subclinical Magnesium Deficiency: A Principal Driver of Cardiovascular Disease and a Public Health Crisis. Open Heart 5, no. 1 (January 1): e000668. 
Dirar HA. 1992. Sudan's fermented food heritage. Applications of Biotechnology to Traditional Fermented Foods," ed. by Board on Science and Technology for International Development, National Academy Press, Washington. 27-34

Domínguez-Rodrigo, M. 2002. Hunting and Scavenging by Early Humans: The State of the Debate. Journal of World Prehistory 16, no. 1: 1-54.

Domínguez-Rodrigo, M., and T.R. Pickering. 2003. Early Hominid Hunting and Scavenging: A Zooarcheological Review. Evolutionary Anthropology: Issues, News, and Reviews 12, no. 6: $275-282$.

Donaldson, G.P., S.M. Lee, and S.K. Mazmanian. 2016. Gut Biogeography of the Bacterial Microbiota. Nature Reviews. Microbiology 14, no. 1 (January): 20-32.

Ejiofor, M., and N. Okafor. 1985. Studies on Microbial Breakdown of Linamarin in Fermenting Cassava. Nig. Food J 2, no. 2-3: 153-158.

El-Abasy, A.E., H.A. Abou-Gharbia, H.M. Mousa, and M.M. Youssef. 2012. Mixes of Carrot Juice and Some Fermented Dairy Products: Potentiality as Novel Functional Beverages. Food and Nutrition Sciences 3, no. 02: 233.

Elizaquível P, Pérez-Cataluña A, Yépez A, Aristimuño C, Jiménez E, et al. 2015.

Pyrosequencing vs. culture-dependent approaches to analyze lactic acid bacteria associated to chicha, a traditional maize-based fermented beverage from Northwestern Argentina. Int. J. Food Microbiol. 198:9-18

Elnabi A. 2008. Microbiology and Chemical Composition of Fermented Bone Based Food (Dodery) from Darfur-Sudan. Unpublished thesis. University of Khartoum, Sudan.

Escalante A, Giles-Gómez M, Hernández G, Córdova-Aguilar MS, López-Munguía A, et al. 2008. Analysis of bacterial community during the fermentation of pulque, a traditional Mexican alcoholic beverage, using a polyphasic approach. Int. J. Food Microbiol. 124(2):126-34 
Faichney, G.J. 1969. Production of Volatile Fatty Acids in the Sheep Caecum. Australian Journal of Agricultural Research. https://sci-

hub.tw/http://www.publish.csiro.au/cp/AR9690491.

Feiner, G. 2016. Chapter 7 - Fermented Salami: Non-Heat Treated. In Salami, 111-176. Academic Press.

Fisberg, M., and R. Machado. 2015. History of Yogurt and Current Patterns of Consumption. Nutrition Reviews 73 Suppl 1 (August): 4-7.

Fischer MM, Egli IM, Aeberli I, Hurrell RF, Meile L. 2014. Phytic acid degrading lactic acid bacteria in tef-injera fermentation. Int. J. Food Microbiol. 190:54-60

Fleming HP, McFeeters RF, Humphries EG. 1988. A fermentor for study of sauerkraut fermentation. Biotechnol. Bioeng. 31(3):189-97

Franz, C.M.A.P., M. Huch, J.M. Mathara, H. Abriouel, N. Benomar, G. Reid, A. Galvez, and W.H. Holzapfel. 2014. African Fermented Foods and Probiotics. International Journal of Food Microbiology 190 (November 3): 84-96.

Garber, P.A. 1987. Foraging Strategies among Living Primates. Annual Review of Anthropology. https://scihub.tw/https://www.annualreviews.org/doi/pdf/10.1146/annurev.an.16.100187.002011.

Gibson, G.R., and R.A. Rastall. 2004. When We Eat, Which Bacteria Should We Be Feeding? ASM News-American Society for Microbiology 70, no. 5: 224-231.

Glander, K.E. 1982. The Impact of Plant Secondary Compounds on Primate Feeding Behavior. American Journal of Physical Anthropology 25, no. S3: 1-18.

Glinsky, M.J., R.M. Smith, H.R. Spires, and C.L. Davis. 1976. Measurement of Volatile Fatty Acid Production Rates in the Cecum of the Pony. Journal of Animal Science 42, no. 6 (June): $1465-1470$. 
Goren-Inbar, N., N. Alperson, M.E. Kislev, O. Simchoni, Y. Melamed, A. Ben-Nun, and E. Werker. 2004. Evidence of Hominin Control of Fire at Gesher Benot Ya`aqov, Israel. Science 304, no. 5671 (April 30): 725-727.

Gray, F.V., R.A. Weller, A.F. Pilgrim, and G.B. Jones. 1967. Rates of Production of Volatile Fatty Acids in the Rumen. V. Evaluation of Fodders in Terms of Volatile Fatty Acid Produced in the Rumen of the Sheep. Australian Journal of Agricultural Research 18, no. 4: $625-634$.

Gubag R, Omoloso DA, Owens JD. 1996. Sapal: a traditional fermented taro [Colocasia esculenta (L.) Schott] corm and coconut cream mixture from Papua New Guinea. Int. J. Food Microbiol. 28(3):361-67

Gupta, R.K., S.S. Gangoliya, and N.K. Singh. 2015. Reduction of Phytic Acid and Enhancement of Bioavailable Micronutrients in Food Grains. Journal of Food Science and Technology 52, no. 2 (February 1): 676-684.

Haard, N.F. 1999. Fermented Cereals: A Global Perspective. Food \& Agriculture Org.

Halm M, Lillie A, Sørensen AK, Jakobsen M. 1993. Microbiological and aromatic characteristics of fermented maize doughs for kenkey production in Ghana. Int. J. Food Microbiol. $19(2): 135-43$

Hambidge, M. 2000. Human Zinc Deficiency. The Journal of Nutrition 130, no. 5S Suppl (May): 1344S-9S.

Hammes, W.P., M.J. Brandt, K.L. Francis, J. Rosenheim, M.F.H. Seitter, and S.A. Vogelmann. 2005. Microbial Ecology of Cereal Fermentations. Trends in Food Science \& Technology 16, no. 1 (January 1): 4-11.

Hatley, T., and J. Kappelman. 1980. Bears, Pigs, and Plio-Pleistocene Hominids: A Case for the Exploitation of Belowground Food Resources. Human Ecology 8, no. 4: 371-387.

Hay, M.E. 2016. Negating the Plant Apparency Model: Rigorous Tests Are the Fuel of Progress. The New Phytologist. Wiley Online Library. 
de Heinzelin, J., J.D. Clark, T. White, W. Hart, P. Renne, G. WoldeGabriel, Y. Beyene, and E. Vrba. 1999. Environment and Behavior of 2.5-Million-Year-Old Bouri Hominids. Science 284, no. 5414 (April 23): 625-629.

Hirata, S., N. Morimura, and C. Houki. 2009. How to Crack Nuts: Acquisition Process in Captive Chimpanzees (Pan Troglodytes) Observing a Model. Animal Cognition 12 Suppl 1 (October): 87-101.

Holloway, R.L. 1970. australopith Endocast (Taung Specimen, 1924): A New Volume Determination. Science 168, no. 3934 (May 22): 966-968.

Holzapfel, W.H. 2002. Appropriate Starter Culture Technologies for Small-Scale Fermentation in Developing Countries. International Journal of Food Microbiology 75, no. 3 (May 25): 197212.

Hoover, W.H., and S.D. Clarke. 1972. Fiber Digestion in the Beaver. The Journal of Nutrition 102, no. 1 (January): 9-15.

Hoover, W.H., and R.N. Heitmann. 1972. Effects of Dietary Fiber Levels on Weight Gain, Cecal Volume and Volatile Fatty Acid Production in Rabbits. The Journal of Nutrition 102, no. 3 (March): 375-379.

Hudson, J.A., S. Hasell, R. Whyte, and S. Monson. 2001. Preliminary Microbiological Investigation of the Preparation of Two Traditional Maori Foods (Kina and Tiroi). Journal of Applied Microbiology 91, no. 5 (November): 814-821.

Hui, Y.H., and E. Özgül Evranuz. 2012. Handbook of Animal-Based Fermented Food and Beverage Technology, Second Edition. CRC Press.

Humer, E., and K. Schedle. 2016. Fermentation of Food and Feed: A Technology for Efficient Utilization of Macro and Trace Elements in Monogastrics. Journal of Trace Elements in Medicine and Biology: Organ of the Society for Minerals and Trace Elements 37 (September): 69-77. 
Iglesias A, Pascoal A, Choupina AB, Carvalho CA, Feás X, Estevinho LM. 2014. Developments in the fermentation process and quality improvement strategies for mead production. Molecules. 19(8):12577-90

Imoto, S., and S. Namioka. 1978. VFA Production in the Pig Large Intestine. Journal of Animal Science 47, no. 2 (August): 467-478.

Innocente N, Biasutti M, Rita F, Brichese R, Comi G, lacumin L. 2016. Effect of indigenous Lactobacillus rhamnosus isolated from bovine milk on microbiological characteristics and aromatic profile of traditional yogurt. LWT - Food Science and Technology. 66:158-64 Isler K., van Schaik C.P. 2006. Metabolic costs of brain size evolution. Biol Lett 2(4): 557-560. Isler K., van Schaik C.P. 2005. Costs of encephalization: The energy trade-off hypothesis tested on birds. J. Hum. Evol. 2006;51:228-243

Isler, K. and Van Schaik, C. 2014. How Humans Evolved Large Brains: Comparative Evidence. Evolutionary Anthropology 23:65-75.

Iqbal, T.H., K.O. Lewis, and B.T. Cooper. 1994. Phytase Activity in the Human and Rat Small Intestine. Gut 35, no. 9 (September): 1233-1236.

James, S.R., R.W. Dennell, A.S. Gilbert, H.T. Lewis, J.A.J. Gowlett, T.F. Lynch, W.C. McGrew, et al. 1989. Hominid Use of Fire in the Lower and Middle Pleistocene: A Review of the Evidence [and Comments and Replies]. Current Anthropology 30, no. 1: 1-26.

Jiménez E, Yépez A, Pérez-Cataluña A, Ramos Vásquez E, Zúñiga Dávila D, et al. 2018. Exploring diversity and biotechnological potential of lactic acid bacteria from tocosh traditional Peruvian fermented potatoes - by high throughput sequencing (HTS) and culturing. LWT - Food Science and Technology. 87:567-74

Jin L., Liu W.C., Li Y.H., Zeng Y., Liao W.B. Evidence for the expensive-tissue hypothesis in the Omei Wood Frog (Rana omeimontis) Herpetol. J. 2015;25:127-130. 
Johnson, J.L., and R.H. McBee. 1967. The Porcupine Cecal Fermentation. The Journal of Nutrition 91, no. 4 (April): 540-546.

Jónsdóttir, G., and K. Leifsdsóttir. 2009. Kennsluefni í Matvælafræði ætlað 9.-10. Bekk í Heimilisfræði. http://skemman.is/handle/1946/3893.

Kabak B, Dobson ADW. 2011. An introduction to the traditional fermented foods and beverages of Turkey. Crit. Rev. Food Sci. Nutr. 51(3):248-60

Kang B-S, Lee J-E, Park H-J. 2014. Qualitative and quantitative prediction of volatile compounds from initial amino acid profiles in Korean rice wine (makgeolli) model. J. Food Sci. 79(6):C1106-16

Katz, S.E. 2012. The Art of Fermentation: An In-Depth Exploration of Essential Concepts and Processes from Around the World. Chelsea Green Publishing.

Katz, S.E. 2016. Wild Fermentation: The Flavor, Nutrition, and Craft of Live-Culture Foods, 2nd Edition. Chelsea Green Publishing.

Kaufman J.A., Hladik C.M., Pasquet P. On the expensive tissue hypothesis: Independent support from highly encephalized fish. Curr. Anthropol. 2003;44:705-707

Kim, J.-D. 2005. Antifungal Activity of Lactic Acid Bacteria Isolated from Kimchi Against Aspergillus Fumigatus. Mycobiology 33, no. 4 (December): 210-214.

Kim, K.I., N.J. Benevenga, and R.H. Grummer. 1978. Lactase Activity and VFA Production in the Cecum and Colon of Pigs Fed a Corn-Soy or $40 \%$ Whey Diet. Journal of Animal Science 46, no. 6 (June): 1648-1657.

Koşar M, Küpeli E, Malyer H, Uylaşer V, Türkben C, Başer KHC. 2007. Effect of Brining on Biological Activity of Leaves of Vitis vinifera L. (Cv. Sultani Çekirdeksiz) from Turkey. J. Agric. Food Chem. 55(11):4596-4603 
Kotrschal A, Rogell B, Bundsen A, Svensson B, Zajitschek S, Brännström I, Immler S, Maklakov AA, Kolm N. Artificial selection on relative brain size in the guppy reveals costs and benefits of evolving a larger brain. Curr Biol. 2013 Jan 21 ;23(2):168-71

Kotrschal A., Corral-Lopez A., Szidat S., Kolm N. The effect of brain size evolution on feeding propensity, digestive efficiency, and juvenile growth. Evolution. 2015;69:3013-3020

Krajmalnik-Brown, R., Z.-E. Ilhan, D.-W. Kang, and J.K. DiBaise. 2012. Effects of Gut Microbes on Nutrient Absorption and Energy Regulation. Nutrition in Clinical Practice: Official Publication of the American Society for Parenteral and Enteral Nutrition 27, no. 2 (April): 201-214.

Langer, P., and Others. 1988. The Mammalian Herbivore Stomach: Comparative Anatomy, Function and Evolution. Gustav Fischer.

Lee, C. H. 1986. Kimchi; Korean fermented vegetable foods. Journal of the Korean Society of Food Culture, 1(4), 395-402.

Leonard WR, Robertson ML, Snodgrass JJ, Kuzawa CW. 2003. Metabolic correlates of hominid brain evolution. Comparative Biochemistry and Physiology Part A: Molecular \& Integrative Physiology 136(1): 5-15.

Lewis, J.E., and S. Harmand. 2016. An Earlier Origin for Stone Tool Making: Implications for Cognitive Evolution and the Transition to Homo. Philosophical Transactions of the Royal Society of London. Series B, Biological Sciences 371, no. 1698 (July 5). http://dx.doi.org/10.1098/rstb.2015.0233.

Liang S, Wu S, Huang Q, Duan S, Liu H, et al. 2017. Rat brain digital stereotaxic white matter atlas with fine tract delineation in Paxinos space and its automated applications in DTI data analysis. Magn. Reson. Imaging. 43:122-28

Liao W.B., Lou S.L., Zeng Y., Kotrschal A. Large brains, small guts: The expensive tissue hypothesis supported in anurans. Am. Nat. 2016;188:693-700 
Liu J., Zhou C.Q., Liao W.B. Evidence for neither the compensation hypothesis nor the expensive-tissue hypothesis in Carassius auratus. Anim. Biol. 2014;64:177-187

Livesey, G. 1995. Short Chain Fatty Acids as an Energy Source in the Colon: Metabokism and Clinical Implication. Physiological and Clinical Aspects of Short Chain-Fatty. https://scihub.tw/https://ci.nii.ac.jp/naid/10019824397/.

Lodolo EJ, Kock JLF, Axcell BC, Brooks M. 2008. The yeast Saccharomyces cerevisiae- the main character in beer brewing. FEMS Yeast Res. 8(7):1018-36

Lopez, A., P. Cacoub, I.C. Macdougall, and L. Peyrin-Biroulet. 2016. Iron Deficiency Anaemia. The Lancet 387, no. 10021 (February 27): 907-916.

Luncz, L.V., T. Proffitt, L. Kulik, M. Haslam, and R.M. Wittig. 2016. Distance-Decay Effect in Stone Tool Transport by Wild Chimpanzees. Proceedings. Biological Sciences / The Royal Society 283, no. 1845 (December 28). http://dx.doi.org/10.1098/rspb.2016.1607.

Lv H-P, Zhang Y-J, Lin Z, Liang Y-R. 2013. Processing and chemical constituents of Pu-erh tea: A review. Food Res. Int. 53(2):608-18

Mackie, R.I. 2002. Mutualistic Fermentative Digestion in the Gastrointestinal Tract: Diversity and Evolution1. Integrative and Comparative Biology 42, no. 2: 319-326.

Mahgoub, S.E.O., and S.A. Elhag. 1998. Effect of Milling, Soaking, Malting, Heat-Treatment and Fermentation on Phytate Level of Four Sudanese Sorghum Cultivars. Food Chemistry61, no. 1 (January 1): 77-80.

Mah, J.-H., K.-S. Kim, J.-H. Park, M.-W. Byun, Y.-B. Kim, and H.-J. Hwang. 2001. Bacteriocin with a Broad Antimicrobial Spectirum, Produced by Bacillus Sp. Isolated from Kimchi. Journal of Microbiology and Biotechnology 11, no. 4:577-584.

Mann, N. 2000. Dietary Lean Red Meat and Human Evolution. European Journal of Nutrition 39, no. 2 (April): 71-79. 
Markowiak, P., and K. Śliżewska. 2017. Effects of Probiotics, Prebiotics, and Synbiotics on Human Health. Nutrients 9, no. 9 (September 15). http://dx.doi.org/10.3390/nu9091021. Marty, J., and M. Vernay. 1984. Absorption and Metabolism of the Volatile Fatty Acids in the Hind-Gut of the Rabbit. The British Journal of Nutrition 51, no. 2 (March): 265-277.

McBurney, M.I. 1994. The Gut: Central Organ in Nutrient Requirements and Metabolism. Canadian Journal of Physiology and Pharmacology 72, no. 3 (March): 260-265.

McGee, H., P. Dorfman, J. Greene, and A. McGee. 2004. Fresh Fermented Milks and Creams. Food and Cooking: The Science and Lore of the Kitchen. New York: Scribner: 44-51.

McGovern PE, Zhang J, Tang J, Zhang Z, Hall GR, et al. 2004. Fermented beverages of preand proto-historic China. Proc. Natl. Acad. Sci. U. S. A. 101(51):17593-98

McGrew, W.C., and W.C. McGrew. 1992. Chimpanzee Material Culture: Implications for Human Evolution. Cambridge University Press.

McHenry, H.M., and K. Coffing. 2000. Australopithecus to Homo: Transformations in Body and Mind. Annual Review of Anthropology. https://sci-

hub.tw/https://www.annualreviews.org/doi/abs/10.1146/annurev.anthro.29.1.125.

McNeil, N.I. 1984. The Contribution of the Large Intestine to Energy Supplies in Man. The American Journal of Clinical Nutrition 39, no. 2 (February): 338-342.

Mercader, J. 2009. Mozambican Grass Seed Consumption during the Middle Stone Age. Science 326, no. 5960 (December 18): 1680-1683.

Messer, J.S., E.R. Liechty, O.A. Vogel, and E.B. Chang. 2017. Evolutionary and Ecological Forces That Shape the Bacterial Communities of the Human Gut. Mucosal Immunology 10, no. 3 (May): 567-579.

Mheen, T.-I., and T.-W. Kwon. 1984. Effect of Temperature and Salt Concentration on Kimchi Fermentation. Korean Journal of Food Science and Technology 16, no. 4: 443-450.

Milton, K. 1986. Digestive Physiology in Primates. Physiology . https://www.physiology.org/doi/abs/10.1152/physiologyonline.1986.1.2.76. 
Milton, K. 1987. Primate Diets and Gut Morphology: Implications for Hominid Evolution. Food and Evolution: Toward a Theory of Human Food Habits: 93-115.

Milton, K. 1999. A Hypothesis to Explain the Role of Meat-Eating in Human Evolution. Evolutionary Anthropology Issues News and Reviews 8, no. 1: 11-21.

Milton, K., and M.W. Demment. 1988. Digestion and Passage Kinetics of Chimpanzees Fed High and Low Fiber Diets and Comparison with Human Data. The Journal of Nutrition 118, no. 9 (September): 1082-1088.

Milton, K., and R.H. McBee. 1983. Rates of Fermentative Digestion in the Howler Monkey, Alouatta Palliata (primates: Ceboidea). Comparative Biochemistry and Physiology. A, Comparative Physiology 74, no. 1:29-31.

Moeller K, Li Y, Ngole E, et al. Rapid changes in the gut microbiome during human evolution. PNAS 111:46, 16431-16435.

Moreno Terrazas R, Escalante A, Giles Gómez M, Esquivel Flores G, Matus Acuña V, et al. 2011. Pulque fermentation. Handbook of plant-based fermented food and beverage technology, 691-706.

Morrison, S.C., and G.P. Savage. 2003. Oxalates.

Morrissey, W.F., B. Davenport, A. Querol, and A.D.W. Dobson. 2004. The Role of Indigenous Yeasts in Traditional Irish Cider Fermentations. Journal of Applied Microbiology 97, no. 3: $647-655$.

Murooka Y, Yamshita M. 2008. Traditional healthful fermented products of Japan. J. Ind. Microbiol. Biotechnol. 35(8):791-98

Navarette, A., Van Schaik, C., and Isler, K. 2011. Energetics and the evolution of human brain size. Nature 480: 91-93.

Nelms, M., and K. Sucher. 2015. Nutrition Therapy and Pathophysiology. Nelson Education.

Ngaba, P.R., and J.S. Lee. 1979. FERMENTATION OF CASAVA (Manihot Esculenta Crantz). Journal of Food Science 44, no. 5 (September 1): 1570-1571. 
Nikmaram, N., S.Y. Leong, M. Koubaa, Z. Zhu, F.J. Barba, R. Greiner, I. Oey, and S. Roohinejad. 2017. Effect of Extrusion on the Anti-Nutritional Factors of Food Products: An Overview. Food Control 79 (September 1): 62-73.

Nile SH. 2015. The nutritional, biochemical and health effects of makgeolli--a traditional Korean fermented cereal beverage. J. Inst. Brew. 121(4):457-63

O'connell, J.F., K. Hawkes, and N.G. Blurton Jones. 1999. Grandmothering and the Evolution of Homo Erectus. Journal of Human Evolution 36, no. 5 (May): 461-485.

O’Connell, J.F., K. Hawkes, and N.B. Jones. 1988. Hadza Scavenging: Implications for Plio/Pleistocene Hominid Subsistence. Current Anthropology. http://scihub.cc/http://www.journals.uchicago.edu/doi/pdfplus/10.1086/203648.

Odunfa SA. 1981. Microorganisms associated with fermentation of African locust bean (Parkia filicoidea) during iru preparation. Journal of Plant Foods. 3(4):245-50

O'Hara, A.M., and F. Shanahan. 2006. The Gut Flora as a Forgotten Organ. EMBO Reports 7, no. 7 (July): 688-693.

Ohland, C.L., and W.K. Macnaughton. 2010. Probiotic Bacteria and Intestinal Epithelial Barrier Function. American Journal of Physiology. Gastrointestinal and Liver Physiology 298, no. 6 (June): G807-19.

Oyedeji O, Ogunbanwo ST, Onilude AA. 2013. Predominant lactic acid bacteria involved in the traditional fermentation of fufu and ogi, two Nigerian fermented food products. Food Nutr. Sci. $4(11): 40$

Padhye VW, Salunkhe DK. 1978. BIOCHEMICAL STUDIES ON BLACK GRAM (PHASEOLUS MUNGO L.) 111. FERMENTATION OF THE BLACK GRAM AND RICE BLEND AND ITS INFLUENCE ON THE IN VITRO DIGESTIBILITY OF THE PROTEINS. J. Food Biochem. 2(4):327-47

Padmaja, G. 1995. Cyanide Detoxification in Cassava for Food and Feed Uses. Critical Reviews in Food Science and Nutrition 35, no. 4 (July): 299-339. 
Palestrant, D., Z.E. Holzknecht, B.H. Collins, W. Parker, S.E. Miller, and R.R. Bollinger. 2004. Microbial Biofilms in the Gut: Visualization by Electron Microscopy and by Acridine Orange Staining. Ultrastructural Pathology 28, no. 1 (January): 23-27.

Pandey, K.B., and S.I. Rizvi. 2009. Plant Polyphenols as Dietary Antioxidants in Human Health and Disease. Oxidative Medicine and Cellular Longevity 2, no. 5 (November): 270-278.

Parker, D.S. 1976. The Measurement of Production Rates of Volatile Fatty Acids in the Caecum of the Conscious Rabbit. The British Journal of Nutrition 36, no. 1 (July): 61-70.

Popovich, D.G., D.J. Jenkins, C.W. Kendall, E.S. Dierenfeld, R.W. Carroll, N. Tariq, and E. Vidgen. 1997. The Western Lowland Gorilla Diet Has Implications for the Health of Humans and Other Hominoids. The Journal of Nutrition 127, no. 10 (October): 2000-2005.

Potts, R. 1984. Home Bases and Early Hominids: Reevaluation of the Fossil Record at Olduvai Gorge Suggests That the Concentrations of Bones and Stone Tools Do Not Represent Fully Formed Campsites but an Antecedent to Them. American Scientist 72, no. 4: 338347.

Prasad, A.S. 2003. Zinc Deficiency. BMJ 326, no. 7386 (February 22): 409-410.

Priyodip, P., P.Y. Prakash, and S. Balaji. 2017. Phytases of Probiotic Bacteria: Characteristics and Beneficial Aspects. Indian Journal of Microbiology 57, no. 2 (June): 148-154.

Rai AK, Tamang JP, Palni U. 2010. Microbiological studies of ethnic meat products of the Eastern Himalayas. Meat Sci. 85(3):560-67

Ramakrishna, B.S. 2013. Role of the Gut Microbiota in Human Nutrition and Metabolism. Journal of Gastroenterology and Hepatology 28 Suppl 4 (December): 9-17.

Ramalhosa E, Gomes T, Pereira AP, Dias T, Estevinho LM. 2011. Mead production: tradition versus modernity. Adv. Food Nutr. Res. 63:101-18

Ramezani, A., Z.A. Massy, B. Meijers, P. Evenepoel, R. Vanholder, and D.S. Raj. 2016. Role of the Gut Microbiome in Uremia: A Potential Therapeutic Target. American Journal of Kidney 
Diseases: The Official Journal of the National Kidney Foundation 67, no. 3 (March): 483498.

Randal Bollinger, R., A.S. Barbas, E.L. Bush, S.S. Lin, and W. Parker. 2007. Biofilms in the Large Bowel Suggest an Apparent Function of the Human Vermiform Appendix. Journal of Theoretical Biology 249, no. 4 (December 21): 826-831.

Ray RC, Sivakumar PS. 2009. Traditional and novel fermented foods and beverages from tropical root and tuber crops. Int. J. Food Sci. Technol. 44(6):1073-87

Rérat, A., M. Fiszlewicz, A. Giusi, and P. Vaugelade. 1987. Influence of Meal Frequency on Postprandial Variations in the Production and Absorption of Volatile Fatty Acids in the Digestive Tract of Conscious Pigs. Journal of Animal Science 64, no. 2 (February): 448456.

Rerksuppaphol, S., and L. Rerksuppaphol. 2018. Zinc Supplementation Enhances Linear Growth in School-Aged Children: A Randomized Controlled Trial. Pediatric Reports 9, no. 4 (January 4). http://www.pagepress.org/journals/index.php/pr/article/view/7294.

Robinson RK, Tamime AY, Wszolek M. 2002. Microbiology of fermented milks. Dairy microbiology handbook: the microbiology of milk and milk products. 367-430. John Wiley \& Sons.

Sandhu, K.S., S. Punia, and M. Kaur. 2017. Fermentation of Cereals: A Tool to Enhance Bioactive Compounds. In Plant Biotechnology: Recent Advancements and Developments, 157-170. Springer, Singapore.

Saono S, Hull RR, Dhamcharee B. 1986. Concise handbook of indigenous fermented foods in the ASCA countries. Canberra, A.G.P.S.

Sarkar P, Tamang JP, Cook PE, Owens J. 1994. Kinema-a traditional soybean fermented food: proximate composition and microflora. Food Microbiol. 11(1):47-55

Sastraatmadja DD, Tomita F, Kasai T. 2002. Production of High-Quality Oncom, a Traditional Indonesian Fermented Food, by the Inoculation with Selected Mold Strains in the Form of 
Pure Culture and Solid Inoculum. Journal of the Graduate School of Agriculture, Hokkaido University= 北海道大学大学院農学研究科紀要. 70(2):111-27

Schoeninger, M.J., H.T. Bunn, S.S. Murray, and J.A. Marlett. 2001. Composition of Tubers Used by Hadza Foragers of Tanzania. Journal of Food Composition and Analysis: An Official Publication of the United Nations University, International Network of Food Data Systems 14, no. 1 (February 1): 15-25.

Schwan RF, Fleet GH. 2014. Cocoa and Coffee Fermentations. CRC Press

Schwan RF, Wheals AE. 2004. The microbiology of cocoa fermentation and its role in chocolate quality. Crit. Rev. Food Sci. Nutr. 44(4):205-21

Scott, G.B. 1980. The Primate Caecum and Appendix Vermiformis: A Comparative Study. Journal of Anatomy 131, no. Pt 3 (October): 549-563.

Seifu E. 2013. Chemical composition and microbiological quality of Metata Ayib: a traditional Ethiopian fermented cottage cheese. Food Chem. Toxicol. 20(1):93

Semaw, S. 2000. The World's Oldest Stone Artefacts from Gona, Ethiopia: Their Implications for Understanding Stone Technology and Patterns of Human Evolution between 2ltextperiodcentered 6--1|textperiodcentered 5 Million Years Ago. Journal of Archaeological Science 27, no. 12: 1197-1214.

Sender, R., S. Fuchs, and R. Milo. 2016. Revised Estimates for the Number of Human and Bacteria Cells in the Body. PLoS Biology 14, no. 8 (August): e1002533.

Şengül M. 2006. Microbiological characterization of Civil cheese, a traditional Turkish cheese: microbiological quality, isolation and identification of its indigenous Lactobacilli. World J. Microbiol. Biotechnol. 22(6):613-18

Sharma A, Sarkar PK. 2015. Microbial diversity in Ethno-fermented foods of Indian Himalayan Region. ENVIS Bulletin Himalayan Ecology. 23:85 
Siciliano-Jones, J., and M.R. Murphy. 1989. Production of Volatile Fatty Acids in the Rumen and Cecum-Colon of Steers as Affected by Forage:concentrate and Forage Physical Form. Journal of Dairy Science 72, no. 2 (February): 485-492.

Skåra, T., L. Axelsson, G. Stefánsson, B. Ekstrand, and H. Hagen. 2015. Fermented and Ripened Fish Products in the Northern European Countries. Journal of Ethnic Foods 2, no. 1 (March 1): 18-24.

Smith, A.R., R.N. Carmody, R.J. Dutton, and R.W. Wrangham. 2015. The Significance of Cooking for Early Hominin Scavenging. Journal of Human Evolution 84 (July): 62-70.

Speth, J.D. 1989. Early Hominid Hunting and Scavenging: The Role of Meat as an Energy Source. Journal of Human Evolution 18, no. 4 (June 1): 329-343.

Sroka P, Tuszyński T. 2007. Changes in organic acid contents during mead wort fermentation. Food Chem. 104(3):1250-57

Stahl, W.R. 1965. Organ Weights in Primates and Other Mammals. Science 150, no. 3699 (November 19): 1039-1042.

Stamer JR, Stoyla BO, Dunckel BA. 1971. Growth rates and fermentation patterns of lactic acid bacteria associated with the sauerkraut fermentation. Journal of milk and food technology. $34(11): 521-25$

Steinkraus K. 1995. Handbook of Indigenous Fermented Foods, Revised and Expanded. CRC Press

Stephan, H., H. Frahm, and G. Baron. 1981. New and Revised Data on Volumes of Brain Structures in Insectivores and Primates. Folia Primatologica; International Journal of Primatology 35, no. 1: 1-29.

Stewart RB, Getachew A. 1962. Investigations of the nature of Injera. Econ. Bot. 16(2):127-30

Swidsinski, A., V. Loening-Baucke, H. Lochs, and L.-P. Hale. 2005. Spatial Organization of Bacterial Flora in Normal and Inflamed Intestine: A Fluorescence in Situ Hybridization 
Study in Mice. World Journal of Gastroenterology: WJG 11, no. 8 (February 28): 11311140.

Tamang JP, Sarkar PK. 1993. Sinki: a traditional lactic acid fermented radish tap root product. J. Gen. Appl. Microbiol. 39(4):395-408

Tennie C., Call J., Tomasello M. 2009. Ratcheting up the ratchet: on the evolution of cumulative culture. Philos Trans R Soc Lond B Biol Sci 364(1528): 2405-2415.

Teramoto Y, Sato R, Ueda S. 2005. Characteristics of fermentation yeast isolated from traditional Ethiopian honey wine, ogol. Afr. J. Biotechnol. 4(2):160-63

Tobias, P.V. 1963. Cranial Capacity of Zinjanthropus and Other australopiths. Nature 197 (February 23): 743-746.

Toth, N., and K. Schick. 2009. The Oldowan: The Tool Making of Early Hominins and Chimpanzees Compared. Annual Review of Anthropology 38, no. 1 (October 1): 289-305.

Tsuboi M., Husby A., Kotrschal A., Hayward A., Buechel S.D., Zidar J., Løvlie H., Kolm N. Comparative support for the expensive tissue hypothesis: Big brains are correlated with smaller gut and greater parental investment in Lake Tanganyika cichlids. Evolution. 2015;69:190-200.

Uno T, Itoh A, Miyamoto T, Kubo M, Kanamaru K, et al. 2009. Ferulic Acid Production in the Brewing of Rice Wine (Sake). J. Inst. Brew. 115(2):116-21

Valadez-Blanco R, Bravo-Villa G, Santos-Sánchez NF, Velasco-Almendarez SI, Montville TJ. 2012. The Artisanal Production of Pulque, a Traditional Beverage of the Mexican Highlands. Probiotics Antimicrob. Proteins. 4(2):140-44

Vanderhoof, J.A. 1998. Immunonutrition: The Role of Carbohydrates. Nutrition 14, no. 7-8 (July): 595-598. 
Vegas C, Mateo E, González A, Jara C, Guillamón JM, et al. 2010. Population dynamics of acetic acid bacteria during traditional wine vinegar production. Int. J. Food Microbiol. 138(12):130-36

Verni, M., C. Wang, M. Montemurro, M. De Angelis, K. Katina, C.G. Rizzello, and R. Coda. 2017. Exploring the Microbiota of Faba Bean: Functional Characterization of Lactic Acid Bacteria. Frontiers in Microbiology 8 (December 12): 2461.

Vincent, A.S. 1985. Plant Foods in Savanna Environments: A Preliminary Report of Tubers Eaten by the Hadza of Northern Tanzania. World Archaeology 17, no. 2 (October): 131148.

Wacher C, Cañas A, Bárzana E, Lappe P, Ulloa M, Owens JD. 2000. Microbiology of Indian and Mestizo pozol fermentations. Food Microbiol. 17(3):251-56

Wadamori, Y., L. Vanhanen, and G.P. Savage. 2014. Effect of Kimchi Fermentation on Oxalate Levels in Silver Beet (Beta Vulgaris Var. Cicla). Foods (Basel, Switzerland) 3, no. 2 (April 23): 269-278.

Wang Q, Peng C, Gong J. 2011. Effects of enzymatic action on the formation of theabrownin during solid state fermentation of Pu-erh tea. J. Sci. Food Agric.

Werge RW. 1979. Potato Processing In The Central Highlands Of Peru Vol-7

Westby A, Twiddy DR. 1992. Characterization ofgari andfu-fu preparation procedures in Nigeria. World J. Microbiol. Biotechnol. 8(2):175-82

Whitman, W.B., D.C. Coleman, and W.J. Wiebe. 1998. Prokaryotes: The Unseen Majority. Proceedings of the National Academy of Sciences of the United States of America 95, no. 12 (June 9): 6578-6583.

World Health Organization. 1997. Carbohydrates in Human Nutrition: Report of a Joint FAO/WHO Expert Consultation. Vol. 66. FAO Food and Nutrition Paper. FAO. 
Wrangham, R.W., J.H. Jones, G. Laden, D. Pilbeam, and N. Conklin-Brittain. 1999. The Raw and the Stolen: Cooking and the Ecology of Human Origins. Current Anthropology 40, no. 5: 567-594.

Yang, E.-J., and H.-C. Chang. 2008. Antifungal Activity of Lactobacillus plantarum Isolated from Kimchi. Microbiology and Biotechnology Letters 36, no. 4: 276-284.

Yang, M.G., K. Manoharan, and O. Mickelsen. 1970. Nutritional Contribution of Volatile Fatty Acids from the Cecum of Rats. The Journal of Nutrition 100, no. 5 (May): 545-550.

Yetneberk S, Rooney LW, Taylor JRN. 2005. Improving the quality of sorghum injera by decortication and compositing with teff. J. Sci. Food Agric. 85(8):1252-58

Yong FM, Wood BJB. 1974. Microbiology and Biochemistry of Soy Sauce Fermentation. In Advances in Applied Microbiology, Vol. 17, ed. D Perlman, pp. 157-94. Academic Press Yoshizawa K. 1999. Sake: Production and flavor. Food Rev. Int. 15(1):83-107Zink, K.D., D.E. Lieberman, and P.W. Lucas. 2014. Food Material Properties and Early Hominin Processing Techniques. Journal of Human Evolution 77 (December): 155-166. 